\title{
INTRODUCTION TO SYMPOSIUM ON THE CONSTITUTIONALIZATION OF INTERNATIONAL LAW IN LATIN AMERICA
}

\author{
Alexandra Huneeus*
}

Had one been pressed, in the mid-1980s, to characterize Latin American approaches to constitutional law and international law, the terms "sleepy" and "sovereigntist" might have come to mind: "sleepy" because judicial review was rare; and "sovereigntist" because ever since declaring independence in a world of colonial powers, Latin American states had asserted a robust version of sovereignty (enshrined, for example, in the Montevideo Convention on the Rights and Duties of States of 1933) and, accordingly, a dualist relation between domestic and international law.

Today, these terms no longer fit. It is still possible, and perhaps even easy, to find a lower judge in rural Mexico bent on strictly applying domestic law alone, or a high court judge in Caracas who sidelines international human rights law under the banner of sovereignty. But if one considers constitutional texts and the practice of the region's judiciaries overall—including high court judges in Bogotá, Brasilia, Buenos Aires, Lima, Mexico City, San Jose, and Santiago-it is clear that the approach to law in general, and to constitutional and international human rights law in particular, has been decisively transformed.

The changes began in 1988 toward the close of the Cold War, when a wave of new constitutions ${ }^{1}$ and interpretive theories began to usher in U.S.-style judicial review (whereby courts claim power to strike down legislation under higher-ranked law). ${ }^{2}$ Latin American rights review, however, developed a dimension absent in U.S. practice. Not only did courts in the region strike down legislation under national constitutions, they began to do so under international human rights treaties as well. Constitutional review became a window through which judges could access, interpret, and directly apply international treaties ratified by the state. Today, while those in the United States are barred from suing under human rights treaties, many Latin Americans have

\footnotetext{
* Associate Professor of Law at the University of Wisconsin Law School.

Originally published online 11 November 2015.

${ }^{1}$ Beginning in 1988, the year of the IACtHR's first contentious judgment, a new generation of constitutions emerged: Brazil (1988), Colombia (1991), Paraguay (1992), Ecuador (1998 and 2008), Peru (1993), Venezuela (1999), and Bolivia (2009) all introduced new constitutions, and Argentina, Mexico, and Costa Rica undertook important constitutional reforms. ${ }^{1}$ While the new constitutions exhibit great variety, they also share important features that were new to the region. They encompassed more rights, including socioeconomic and community rights, and more procedural mechanisms for their protection. They also embraced international human rights treaty law, often explicitly granting it a high rank in domestic law.

${ }^{2}$ Latin American countries actually have a long history of judicial review: the nineteenth-century constitutions of both Colombia and Mexico formally established judicial review. But the practice was less widespread and less frequently invoked prior to the 1990s. Further, a finding of violation would lead to the law not being applied in the particular case only. Finally, it was particularly rare for an individual to successfully challenge legislation as a violation of individual rights. Manuel José Cepeda-Espinosa, Ludicial Activism in a Violent Context: The Origin, Role, and Impact of the Colombian Constitutional Court, 3 WASH. U. GLOBAL STUD. L. REV. 529, 538-539 (2004) (arguing that Colombia's nineteenth-century constitution had judicial review); Vicente Fernández Fernández \& Nitza Samaniego Behar, El juicio de amparo: historia y future de la protección constitucional en México The Trial of Amparao: its History and the Future of this Constitutional Protection in Mexico], 27 Revista del Instituto de Ciencias Juridicas De Puebla 173, 174 (2011) (showing that Mexico's 1841 Constitution included the writ of amparo).
} 
standing to directly challenge laws under treaty-based human rights in domestic court. As in Europe, the meaning of the American Convention on Human Rights (ACHR), the Indigenous and Tribal Peoples Convention, the Rome Statute and other treaties are being worked out, and their influence felt, through myriad local disputes around the region, regardless of whether these disputes ever reach an international body. And as in Europe, courts around the region cite to each other and to the Inter-American Court of Human Rights (IACtHR) in their rulings, creating a shared transnational jurisprudence on human rights law.

Many applaud these changes as a progressive development that helps entrench the rule of law, protect rights and deepen democracies. But there are voices on the Right and Left alike that seek to quell if not reverse their advance. Both sides note with irony that the practice of strong-form judicial review, which is after all an antimajoritarian form of authority, took root just as democracy spread in the region. ${ }^{3}$ Even those who generally accept constitutional review as a legitimate check may balk at the practice of striking down legislation under treaties, using the jurisprudence of foreign judges. For progressives with a sense of history, it is unclear in what universe Latin American judges could possibly be trusted to act as a progressive force. And for conservatives, it is hard to accept that priority be given to a body of law which, until recently, was viewed as a political (as opposed to legal) doctrine animated by progressive ideals.

This AJIL Unbound Symposium aims to introduce U.S. scholars and practitioners to this vibrant and controversial new era of global human rights law in the Americas. ${ }^{4}$ The Symposium gathers four key thinkers and asks them to reflect on one of its most effervescent sites: the interaction of the Inter-American Human Rights Court and domestic judiciaries. Taken together, the essays provide insight into the transformation of what was once a region of legalist interpretive theory and sovereigntist states into a more cosmopolitan, integrated and rights-oriented legal realm. While similar changes have unfolded in Europe, Latin American practice has developed new legal forms, and reveals that rights law can become integrated across boundaries even absent economic integration. The changes, moreover, have implications beyond law. To understand most political struggles in Latin America today-be it the Mexican government's effort to curb drug-gang violence; the peace process in Colombia; or battles over mining, oil, and forestry projects the region over-a grasp of the new relation between constitutional and international law and courts proves vital.

\section{The Four Essays}

The Symposium begins with two essays that reflect on the doctrine of conventionality control, which is in some ways the high-water mark of the constitutionalization of human rights law in the Americas. Conventionality control refers to the practice by which domestic courts review legislation not only under constitutional texts, but also directly under an international treaty. In Almonacid v. Chile (2006), the Inter-American Court of Human Rights announced that all judges must review domestic laws for conformity to the ACHR. If there is a conflict, the Court held, the domestic law cannot be applied.

This interpretation of the American Convention marked a sea change. In the past, it was clear that states, as a whole, were subject to and had duties under the ACHR. But what this duty meant for distinct actors within

\footnotetext{
${ }^{3}$ Judicial review in the region has taken the form of what Mark Tushnet calls strong-form review, which, as in U.S. practice, "insists that the courts' reasonable constitutional interpretations prevail over the legislatures' reasonable ones. . . their interpretive judgments are final and unrevisable." MARK TUSHNET, WEAK COURTS, STRONG RIGHTS: JUDICIAL REVIEW AND SOCIAL WELFARE RIGHTS IN COMPARATIVE CONSTITUTIONAL LAW 21 (2009).

${ }^{4}$ The United States is a State Party to the OAS Charter, which commits states to uphold human rights, and creates the Inter-American Human Rights Commission. While the Charter does not set out a bill of rights, many hold the view that the American Declaration of Human Rights articulates the rights alluded to by the Charter. The United States has not ratified the American Convention of Human Rights and has not accepted the jurisdiction of the Inter-American Court of Human Rights. Thus, while it participates in the OAS Human Rights System and is subject to supervision by the Commission, it has not taken on the full set of obligations.
} 
the state depended on domestic law. While, as discussed above, many judiciaries in the region already reviewed laws for conformity to human rights treaties, they did so because their domestic constitutions mandated or allowed it. Thus, the Argentine constitution of 1994 granted the American Convention constitutional rank in a system of diffuse constitutional review. ${ }^{5}$ Chile, by contrast, had a more concentrated system of review, and most judges viewed themselves as bound to apply legislation. With Almonacid, the IACtHR seemed to be saying that all states had to be more like Argentina-constitutional texts notwithstanding. The Court rendered the growing practice of judicial review under the American Convention a legal obligation.

In the first essay, Inter-American Court judge and Mexican scholar Eduardo Ferrer Macgregor explains the evolution and grounding of the Inter-American Court's doctrine of conventionality control, arguing for its legal legitimacy and positive political consequences. ${ }^{6}$ Judge Ferrer is one of the most distinguished advocates of this doctrine, and had written extensively on it before assuming his judgeship.

In a response essay, scholar and Inter-American System lawyer Ariel Dulitzky counters that, through its understanding of conventionality review, the Inter-American Court has usurped too much power. ${ }^{7}$ By reading the ACHR as establishing a constitutional system with itself as peak court, the IACtHR squelches the input of domestic judiciaries into the development human rights law. He proposes an alternative ordering in which the IACtHR and fellow domestic courts together develop ACHR jurisprudence through a judicial dialogue among equals.

While the first two essays reflect on what might be termed the constitutionalization of the American Convention on Human Rights, the third turns to the concomitant internationalization of constitutional law. As national courts develop jurisprudence on human rights, they borrow from and build on each other as well as the Inter-American Court. This regional judicial dialogue has intensified in recent years. Armin von Bogdandy, one of the figures who has spearheaded scholarship on this judicial exchange from the distant vantage-point of the Max Planck Institute, describes the emergence of a ius constitucionale commune en America Latina (ICCAL)a shared law of fundamental rights in the Americas. ${ }^{8}$ Bogdandy's essay introduces the concept of ICCAL, and argues for its value as a progressive force. Even as he notes the pitfalls and possible criticisms such a conception of law could engender, he imagines that the development of a core set of shared constitutional guarantees through transnational judicial dialogue can help offset some of the region's ills, such as economic inequality, corruption and discrimination.

Bogdandy's ICCAL resonates with both Judge Ferrer's argument in favor of conventionality control and Dulitzky's vision of a robust judicial dialogue on human rights norms: for all three, the courts have an important role to play in the construction of a shared rights-based jurisprudence. ICCAL's claim is that it will result in progressive, political change even as it remains well within the liberal bounds of traditional constitutional democracy.

Roberto Gargarella's essay calls this optimism on rights into question. ${ }^{9}$ Throught the lens of the case of Gelman v. Uruguay, the Argentine theorist argues that the problem with conventionality control is not that it squelches the role of domestic judiciaries, but that it squelches democracy itself. The Gelman case forms part of a string of celebrated IACtHR cases striking down amnesties in the region. But Uruguay's amnesty, Gargarella argues, was different. In contrast to those of Brazil, Chile, Peru, and Salvador, it was not promulgated

5 Art. 72 (22), CONSTiTUCiÓN NACIONAL [Const. Nac.] (Arg.).

${ }^{6}$ Eduardo Ferrer Mac-Gregor, Conventionality Control: The New Doctrine of the Inter-American Court of Human Rights, 109 AJIL UNBOUND 93 (2015).

7 Ariel E. Dulitzky, An Alternative Approach to the Conventionality Control Doctrine, 109 AJIL UnBound 100 (2015).

8 Armin von Bogdandy, Ius Constitutionale Commune en América Latina: Observations on Transformative Constitutionalism, 109 AJIL UNBOUND 109 (2015).

${ }_{9}^{9}$ Roberto Gargarella, Democracy and Rights in Gelman v. Uruguay, 109 AJIL Unbound 115 (2015). 
by an authoritarian regime attempting to shield itself from prosecution. Rather, Uruguay's amnesty was passed by a democratic successor government. It was then upheld by two popular referenda held two decades apart. It is hard to imagine a law with a more solid democratic pedigree. Gargarella systematically argues against this usurpation of deliberative democratic decision-making by an international rights court, suggesting that a more fluid, dialogic interaction with the political branches would be more appropriate. His discussion of Gelman forms part of a broader critique of Latin America's human rights turn as prioritizing judicial over democratic deliberation, punishment over other forms of reproach, and lists of rights over more effective constitutional reforms.

\section{Conclusion}

Recent scholarship has sought to rescue the historical role of Latin American states in creating the postwar world order, and on insisting that it emphasize human rights. ${ }^{10}$ Latin American states, for example, created the world's first international human rights declaration (the American Declaration of Rights and Duties of Man); and played an important role in ensuring that the UN Charter make mention of human rights, and in insisting on a universal rights declaration. New scholarship also emphasizes the role of Latin American actors, and the human rights system of the Organization of American States (OAS), in the human rights turn in transnational activism starting in the 1970s. ${ }^{11}$ While it may not make sense today to argue for an American International Law-something for which Chilean jurist Alejandro Alvarez and his school of followers argued in the early $20^{\text {th }}$ century - it seems important to acknowledge, and to critically evaluate, not only the region's historical but also its contemporary role in forging innovative doctrines and practices around international human rights law. ${ }^{12}$

${ }^{10}$ Mary Ann Glendon, The Forgotten Crucible: The Latin American Influence on the Human Rights Idea, 16 HARv. HuM. RTS. J. 27, 31 (2003); see also Kathryin Sikkink, Latin American Countries as Norm Protagonists of the Idea of International Human Rights, 20 GLOBAL GOVERNANCE 389 (2014); Hector Espiell, La Declaración Americana: Raices Conceptuales y Políticas En La Historia, La Filosofia Y El Derecho Americano, Revista del Instituto Interamericano de Derechos Humanos, Edicion Especial 41 (1989).

11 Patrick William Kelly, "Magic Words": The Advent of Transnational Human Rights Activism in Latin America's Southern Cone in the Long 1970s, in The Breakthrough: Human Rights in the 1970s 88 (Jan Eckel \& Samuel Moyn eds., 2013).

$12 \underline{I d}$. 